\title{
Democratic Consolidation beyond Political Crisis: An Experience of Korea
}

\author{
Lee Dong-Yoon and Lee Jaehyon *
}

In late 20th century, the East Asian region joined the world-wide democratic trend of "the third wave. ${ }^{1}$ Once formidable authoritarian regimes were dismantled and gave way to democratization. The trend began in the Philippines in 1986 and it was followed by South Korea and Taiwan both in 1987. Thailand joined the club in 1992 and Indonesia did the same a couple of years before the new millennium. In those countries, new democratic constitutions were written. With the new constitutions, freedom of political participation was bestowed upon ordinary citizens, civil organizations, political parties, and so on. Free and fair elections have been regularly held since then and the elections, reflecting the hopes of ordinary citizens, installed new civilian political leadership.

Not all democratic transitions and consolidations in those countries, however, were without crisis. Despite free and competitive elections and political participation guaranteed by constitutions and by the laws related to elections and political parties, the marches towards further democracy in those countries often look unstable and confusing. The instability was partly due to a sudden explosion of political demands, which had been suppressed for a long time under authoritarian rule. The plethora of political demands could not be smoothly aggregated and articulated in the new born democratic political systems. If the instability of a newly democratized political system continues, then it may endanger the sustainability of a new democracy causing reversal of democracy or return to authoritarianism.

Korea, after democratization, has been plagued by various political crises too. The economic crisis in 1997 was a grave test for Korean democracy. With the economic crisis, Korea, for the first time, experienced a peaceful change of political power. Korea's march towards democracy was thereafter relatively smooth despite minor political scandals. In spring 2004, Korea suddenly plunged into a political crisis when President Roh Moo-Hyun faced impeachment proceedings. This crisis brought about a serious division not only among politicians, but also among ordinary citizens. Also, hot debates on the constitution, on political leadership and civil society were incurred. The presidential impeachment was the first in Korea's history. It, however, became an important turning point of democratic progress when political leaders and civil society successfully managed and overcame the crisis.

This study will first analyze democratic transition and consolidation and secondly analyze the causes of and responses to the political crisis caused by the impeachment of the president through examining the following questions. The main questions of this study are as follows: How did the democratic transition and consolidation in Korea occur? What was the nature of political crisis in Korea after democratization? What was the main reason of the crisis? What sort of problems did the political leadership and civil society have? How did Korea respond to the crisis and overcome the crisis of presidential impeachment? What implications does this process from the beginning to the end of the crisis have for Korean democracy after democratization? Particularly, this study focuses on the political leadership and the political behavior of civil society in the process of democratic transition and consolidation. With these

\footnotetext{
Dong-Yoon Lee is Professor of International Relations at Silla University, South Korea (jeby0070 @unitel.co.kr). Jaehyon Lee is a post-doc fellow at the Department of Political Science and International Studies, Yonsei University, South Korea (jbintang@gmail.com).
} 
two variables, the authors analyze the 2004 presidential impeachment and shed light on the implication of the crisis from the angle of democratic consolidation.

\section{Democracy after Democratization: Political Crisis and Democratic Consolidation}

'Democracy' is defined in many different ways, but in general is conceptualized as "a political system in which rulers acquire legitimacy to govern by the consent of ordinary citizens and the representatives are selected through free and fair elections". ${ }^{2}$ When we discuss democracy, it is often related to polyarchy. If the core of democratic political system is described as a polyarchy, it should meet some conditions. First, meaningful 'competition' among individuals or organized groups must be guaranteed. In this competition for public positions, all participants should follow predetermined rules while resorting to violence is not allowed. Second, comprehensive 'political participation' is permitted in selecting leaders and policies through fair elections conducted lawfully. Third, 'political and civil freedom' is not constrained so that the above mentioned elements are fully expressed and realized. ${ }^{3}$ Extending this concept, 'democratic consolidation' means that "a newly formed democratic system is sustained and attempts to return to authoritarianism or to reverse democracy are prevented."

However, polyarchy is a democracy in minimalist sense. ${ }^{5}$ Democratic consolidation is not automatically guaranteed after democratization. A new regime may swing back and forth between authoritarianism and democracy. ${ }^{6}$ For a political system to be democratic, we need more than polyarchy. Today, many debates on democracy only touch on procedural and institutional democracy, i.e. 'electoral democracy'. This concept, however, faces criticism that electoral democracy has institutional features to elect representatives in a fair and democratic manner, but it has limitations in terms of securing the interests of minorities and promoting social tolerance, and may be limited by low civil participation. Thus, it still falls short of fully guaranteeing civil liberty and rights. ${ }^{7}$ Electoral democracy promotes competition among political actors. It cannot, however, in its real operation, effectively prevent the emergence of hegemonic parties nor prevent the abuse of political power. This abnormality may endanger democratic politics and bring about a competitive but authoritarian system. ${ }^{8}$

Therefore, we need more than simple electoral democracy and this is what we mean by democratic consolidation. Then, what constitutes a consolidated democracy? For a democracy to continue to exist and to be consolidated, both democratic institutions and the substance to operate the institutions are needed as preconditions. That is what is meant by 'substantive' democracy, as compared to 'institutional' or 'procedural' democracy. ${ }^{9}$ The level of democracy is gauged by the political orientations of political leaders and ordinary citizens. If democratic transition means institutional change, then consolidation can be understood in the context of political attitude and orientation. If 'procedural-institutional' means how to elect political leaders, 'substantive' means what political actors do and how in actual politics. ${ }^{10}$

Establishing institutional and procedural democracy in the process of democratization and democratic transition does not guarantee the success and continuity of a new democracy. Without substantive conditions such as a democratic attitude and orientation in civil society, the new democracy is vulnerable to political crisis. Newly established democratic political institutions and electoral competition are often abused by political leaders, who remain comfortable with authoritarian practices, to maintain and prolong political power. The former authoritarian political attitude and orientation of civil society, which may not adapt to the changed environment but instead repeat old practices, can invite political crisis as well. 'Delegative', 'immature', 'imperfect', and 'unstable' democracy describes such situation. ${ }^{11}$ 
Symptoms of such political systems include imbalances of power distribution, a lack of checks and balances, the deprivation of minority political rights, unaccountable government, and corruption. If these symptoms are rampant, then it causes a return to authoritarianism or setback of democracy. ${ }^{12}$

The concept of 'illiberal democracy' is an example of distorted democracy at the stage of democratic transition and consolidation. ${ }^{13}$ Illiberal democracy "allows wide civil liberty, but at a critical juncture this liberty is partly or totally denied". ${ }^{14}$ In other words, liberal and illiberal elements are all mixed in a transitional political structure and orientation of people in the transition period from authoritarianism to democracy. ${ }^{15}$ Such political systems are neither democratic nor authoritarian in terms of political attitude and orientation. On the one hand, institutionally and procedurally democratic elements are in place, unlike in authoritarian systems where political competition is not allowed. On the other hand, however, many old authoritarian political practices remain.

New democracies not only face the problem of old authoritarian legacies, but they also have to tackle new issues that spring up in the process of democratizing political structures and society. ${ }^{16}$ Politics is a process in which solutions for social issues are searched for through interactions between political leaders and people. Also it is a power phenomenon that causes political and social changes. Therefore, the attitudes and orientations of political leadership and civil society can cause political crises in the process of democratic transition and consolidation. ${ }^{17}$ The behavior and strategy of political leaders who mobilize political support and resources to fulfill specific political purposes is important in transition. In addition, low political participation of civil society and gradually increasing individualism may endanger the basis of nascent democracy. In a new democracy, if political leaders and civil society do not credit newly established political institutions and do not have mutual confidence, the political system is destined to face grave crisis. ${ }^{18}$

The new leadership style needed in the transition and consolidation stage is not a leadership of 'order and control', prevalent under authoritarian governance, but a leadership of 'mediation and coordination' that works out compromise among the competing interests. This shift from 'order and control' to 'mediation and coordination' means a transition from an authoritarian leadership to a democratic leadership. ${ }^{19}$ The most common problem with political leadership in transition periods is protracted 'monarchical' political leadership, a legacy of authoritarian politics. With such leadership, political leaders in transition period try to exercise absolute power, concentrating political power in their own hands. Also, the leaders attempt to rationalize the centralization of political power with people's support and procedural-institutional justification. Political leadership has significant impacts not only in the transition period, but also during the consolidation process. In this process, the major questions to the political leadership are what tasks must be accomplished and how to best accomplish them, differentiating it from authoritarian leadership.

The political attitude and orientation of civil society is also crucial in democratic consolidation. For a democracy to function effectively, a system of checks and balances must be established, and this system must function such that civil society can feel confident that the state is acting in accordance with the laws set out in the constitution. Civil society in a postdemocratization period faces a dilemma. On the one hand, the capacity of civil society and of political actors that brought about democratization suddenly decreases after democratization. On the other hand, conflicts along ethnic and religious divisions and socioeconomic gaps emerge as major threats to new democracies. ${ }^{20}$ Undemocratic attitudes and behaviors of civil society, which were grown under authoritarian suppression in the old days, must be checked incessantly. Otherwise, democratic system in post democratization period cannot be sustained. In addition, problems in civil society such as non-democratic practices, lack or weakness of 
organizations by which civil society can represent its interests, and the lack of healthy relationships between civil society and political parties should be fixed for a more complete democracy. $^{21}$

In conclusion, democratic consolidation based on the substantive concept of democracy is that political actors including political leaders and civil society deem democratic institutions and procedures most appropriate and this belief is embedded and internalized in their social and political life. ${ }^{22}$ To maintain and sustain democracy, autonomy of political life and social life should be found in the context of rule of law. ${ }^{23}$ This means that political leaders and civil society alike have to consider democratic practice as the sole 'rule of game' that defines political process. Political stability and social order is decided by the relationship between political leaders and ordinary citizens. Therefore, democratic consolidation requires more effort by the political leadership and civil society to embed and internalize democratic procedures and practices.

\section{Problems of Democratic Transition and Consolidation: Between Political Leadership and Civil Society}

Democratization in Korea was a consequence of strategic choices made by authoritarian and democratic forces. ${ }^{24}$ Since 1984 , critical social movements grew in civil society, indebted to softer control of the society by the state. In 1985, the New Democratic Party emerged as the primary opposition party through the 12 th general election. Since then, Korean politics has swung back and forth between negotiation and confrontation, i.e. mass mobilization against authoritarian power and coercion of it by the authoritarian power. In 1987 the government heightened the level of suppression to regain control over society. At the end, negotiations for direct popular presidential elections were shattered. The government's attempt to conceal the death of a student protester, Park Jong Chul, who died after torture while in policy custody, was revealed. These two events dramatically ignited the June Democratic Struggle (Yuwol Minjuhangjaeng).

Essentially, democratization in Korea was a compromise between mass mobilization from the bottom and concession from the top. The compromise took the form of the "6.29 statement" (Yukigu Sunun) by then presidential candidate, Roh Tae Woo, of the ruling party. A good chance for power transition came with the 1987 presidential election and the 13th general election in 1988. A democratic force including opposition parties, however, failed to field a single candidate for the presidential election and continuously exposed internal divisions. Thus, Roh Tae Woo from the ruling party won the election. Thereafter, the dominant authoritarian bloc and the smaller democratic bloc entered into a prolonged contest for power and democratic political reforms have been achieved in a piecemeal and gradual manner over the course of the next few elections.

Although democratization is no longer considered a linear process, democratization in Korea, from the decay of authoritarian rule to democratic transition, was relatively quick and straightforward. ${ }^{25}$ According to the Freedom Index by Freedom House, as shown in Table 1, other East Asian democratized countries made slow progress toward 'Free' status. ${ }^{26}$ But Korea swiftly moved to 'Free' status in 1988 and maintained that status thereafter. In addition, while some countries like Thailand and the Philippines marched slowly to 'Free' status and regressed to 'Partly Free' status, Korea has maintained its 'Free' status without break. 
Table 1. Freedom Index of East Asian Countries (1985 2006)

\begin{tabular}{|c|c|c|c|c|c|c|c|c|c|c|c|c|c|c|c|}
\hline \multirow{2}{*}{ Year } & \multicolumn{3}{|c|}{ South Korea } & \multicolumn{3}{|c|}{ Taiwan } & \multicolumn{3}{|c|}{ Philippines } & \multicolumn{3}{|c|}{ Thailand } & \multicolumn{3}{|c|}{ Indonesia } \\
\hline & PR & $\overline{C L}$ & $\mathrm{~S}$ & $P$ PR & $\overline{C L}$ & $\mathrm{~S}$ & PR & $\mathrm{CL}$ & $\mathrm{S}$ & PR & $\mathrm{CL}$ & $\mathrm{S}$ & PR & $\mathrm{CL}$ & $\mathrm{S}$ \\
\hline 1985 & 4 & 5 & $\mathrm{PF}$ & 5 & 5 & $\mathrm{PF}$ & 4 & 3 & $\mathrm{PF}$ & 3 & 4 & $\mathrm{PF}$ & 5 & 6 & $\mathrm{PF}$ \\
\hline 1986 & 4 & 5 & $\mathrm{PF}$ & 5 & 5 & $\mathrm{PF}$ & 4 & 2 & $\mathrm{PF}$ & 3 & 3 & $\mathrm{PF}$ & 5 & 6 & $\mathrm{PF}$ \\
\hline 1987 & 4 & 4 & $\mathrm{PF}$ & 5 & 4 & PF & 2 & 2 & $\mathrm{~F}$ & 3 & 3 & $\mathrm{PF}$ & 5 & 6 & $\mathrm{PF}$ \\
\hline 1988 & 2 & 3 & $\mathrm{~F}$ & 5 & 3 & PF & 2 & 3 & $\mathrm{~F}$ & 3 & 3 & $\mathrm{PF}$ & 5 & 5 & $\mathrm{PF}$ \\
\hline 1989 & 2 & 3 & $\mathrm{~F}$ & 4 & 3 & $\mathrm{PF}$ & 2 & 3 & $\mathrm{~F}$ & 2 & 3 & $\mathrm{~F}$ & 5 & 5 & $\mathrm{PF}$ \\
\hline 1990 & 2 & 3 & $\mathrm{~F}$ & 3 & 3 & $\mathrm{PF}$ & 3 & 3 & $\mathrm{PF}$ & 2 & 3 & $\mathrm{~F}$ & 6 & 5 & $\mathrm{PF}$ \\
\hline 1991 & 2 & 3 & $\mathrm{~F}$ & 5 & 5 & $\mathrm{PF}$ & 3 & 3 & $\mathrm{PF}$ & 6 & 4 & PF & 6 & 5 & $\mathrm{PF}$ \\
\hline 1992 & 2 & 3 & F & 3 & 3 & $\mathrm{PF}$ & 3 & 3 & $\mathrm{PF}$ & 3 & 4 & PF & 6 & 5 & $\mathrm{PF}$ \\
\hline 1993 & 2 & 2 & $\mathrm{~F}$ & 4 & 4 & $\mathrm{PF}$ & 3 & 4 & $\mathrm{PF}$ & 3 & 5 & PF & 7 & 6 & $\mathrm{NF}$ \\
\hline 1994 & 2 & 2 & $\mathrm{~F}$ & 3 & 3 & $\mathrm{PF}$ & 3 & 4 & PF & 3 & 5 & PF & 7 & 6 & $\mathrm{NF}$ \\
\hline 1995 & 2 & 2 & $\mathrm{~F}$ & 3 & 3 & $\mathrm{PF}$ & 2 & 4 & PF & 3 & 4 & PF & 7 & 6 & NF \\
\hline 1996 & 2 & 2 & $\mathrm{~F}$ & 2 & 2 & $\mathrm{~F}$ & 2 & 3 & $\mathrm{~F}$ & 3 & 3 & PF & 7 & 5 & NF \\
\hline 1997 & 2 & 2 & $\mathrm{~F}$ & 2 & 2 & $\mathrm{~F}$ & 2 & 3 & $\mathrm{~F}$ & 3 & 3 & $\mathrm{PF}$ & 7 & 5 & $\mathrm{NF}$ \\
\hline 1998 & 2 & 2 & F & 2 & 2 & $\mathrm{~F}$ & 2 & 3 & $\mathrm{~F}$ & 2 & 3 & $\mathrm{~F}$ & 6 & 4 & $\mathrm{PF}$ \\
\hline 1999 & 2 & 2 & $\mathrm{~F}$ & 2 & 2 & $\mathrm{~F}$ & 2 & 3 & $\mathrm{~F}$ & 2 & 3 & $\mathrm{~F}$ & 4 & 4 & $\mathrm{PF}$ \\
\hline 2000 & 2 & 2 & F & 1 & 2 & $\mathrm{~F}$ & 2 & 3 & $\mathrm{~F}$ & 2 & 3 & $\mathrm{~F}$ & 3 & 4 & $\mathrm{PF}$ \\
\hline 2001 & 2 & 2 & $\mathrm{~F}$ & 1 & 2 & $\mathrm{~F}$ & 2 & 3 & $\mathrm{~F}$ & 2 & 3 & $\mathrm{~F}$ & 3 & 4 & $\mathrm{PF}$ \\
\hline 2002 & 2 & 2 & $\mathrm{~F}$ & 2 & 2 & $\mathrm{~F}$ & 2 & 3 & $\mathrm{~F}$ & 2 & 3 & $\mathrm{~F}$ & 3 & 4 & $\mathrm{PF}$ \\
\hline 2003 & 2 & 2 & $\mathrm{~F}$ & 2 & 2 & $\mathrm{~F}$ & 2 & 3 & $\mathrm{~F}$ & 2 & 3 & $\mathrm{~F}$ & 3 & 4 & $\mathrm{PF}$ \\
\hline 2004 & 1 & 2 & $\mathrm{~F}$ & 2 & 1 & $\mathrm{~F}$ & 2 & 3 & $\mathrm{~F}$ & 2 & 3 & $\mathrm{~F}$ & 3 & 4 & $\mathrm{PF}$ \\
\hline 2005 & 1 & 2 & $\mathrm{~F}$ & 1 & 1 & $\mathrm{~F}$ & 3 & 3 & $\mathrm{PF}$ & 3 & 3 & PF & 2 & 3 & $\mathrm{~F}$ \\
\hline 2006 & 1 & 2 & F & 2 & 1 & $\mathrm{~F}$ & 3 & 3 & $\mathrm{PF}$ & 7 & 4 & $\mathrm{NF}$ & 2 & 3 & F \\
\hline
\end{tabular}

* PL (Political Rights), CL (Civil Liberty), St. (Status), NF (Not Free), PF (Partly Free), F (Free)

Source: Freedom House. Http://www.freedomhouse.org (Search Date: April 6, 2007).

Unlike what was shown in Table 1, however, Korea's democratic transition and consolidation was not without problems. Various challenges to political leadership caused political crises. The political leadership in Korea since the democratization is not a genuine democratic leadership. Presidential leadership after democratization still had authoritarian nature and did not shed off the old role of president as a commander rather than facilitator or coordinator. ${ }^{27}$ Former authoritarian presidents often exploited Confucian ideals and values, characterized by hierarchical and authoritarian order, to justify non-democratic political institutions and practices. Even after democratization, political leaders were tempted to rely on authoritarian legacies to legitimize the arbitrary use of state power for their own political purposes. ${ }^{28} \mathrm{We}$ can put aside former president Roh Tae Woo who became president right after 1987 democratization. Civilian presidents after democratization such as Kim Young Sam and Kim Dae Jung were not free from criticism of their leadership styles. ${ }^{29}$ Their leadership often is described as 'monarchical leadership' which did not depart much from authoritarian legacy. ${ }^{30}$ Rather than seeking cooperation and compromise when their ruling parties were in the minority, these two presidents caused conflict and confrontation with opposition, bringing about political instabil- 
ity. Most political leaders who took power after democratization did not completely do away with past authoritarian political behavior, but spent most of their time and energy in playing with rhetoric of reform. After retirement, their images were further ruined by corruption cases. $^{31}$

Corruption has weakened the political leadership of every president since the democratization. Each administration, in its initial stage, renewed pledges to clean up corruption and attempted related law-making. All these efforts, however, were tarnished when almost every president's close allies or family members were revealed to have been involved in corruption cases. ${ }^{32}$ President Roh Tae Woo, who was a president in the transition period from authoritarianism to democratization, was sentenced and put into jail because of a so-called 'ruling fund,' raised and kept illegally. President Kim Young Sam announced 'no-holds-barred clearing up corruption' and 'reform from above', but his leadership was severely damaged by a corruption case in which his son was involved. ${ }^{33}$ Likewise, President Kim Dae Jung did well in early days of presidency, as his moves such as successful management of economic crisis, North-South Summit and so on. He received popular support, but his success was short-lived. He lacked skill in coordinating and managing policies such as healthcare. His early success was further undermined by corruption cases in which his son and close allies were involved. Regarding rooting out corruption, President Kim Dae Jung announced strong anti-corruption policies, especially focusing on bureaucracy, which was symbolized by the establishment of the Korea Independent Commission Against Corruption (KICAC). ${ }^{34}$ But, cleaning corruption was not an easy task. His leadership was damaged when his sons were also found guilty of corruption.

Political behavior and orientation as well as the role of civil society are crucial in stabilizing democratic transition and consolidating democracy. After democratization in Korea, the power balance between the state and civil society has changed dramatically. The activities of civil organizations have increased substantially and the cooperative relationship between the government and the civil society has increased substantially. This lively civil society prompted the coining of a new term, 'NGO phenomenon'. The president and the national assembly could not ignore the influential opinions of the civil organizations. ${ }^{35}$ For example, the movement of blacklisting irrelevant candidates for the 2000 National Assembly election displayed the power and influence of the civil organizations. In addition, an open primary was held for the presidential election in 2002. In that election, civil organizations including netizen's participation in the electoral process via the internet had very decisive impact on the election result.

Table 2. Comparison of Trust on Institutions in 2002 and 2007

\begin{tabular}{|c|c|c|c|c|c|c|c|c|c|c|c|c|}
\hline & \multicolumn{2}{|c|}{$\begin{array}{c}\text { Civil } \\
\text { groups }\end{array}$} & \multicolumn{2}{|c|}{ Military } & \multicolumn{2}{|c|}{ Police } & \multicolumn{2}{|c|}{ Judicature } & \multicolumn{2}{|c|}{ Administration } & \multicolumn{2}{|c|}{$\begin{array}{c}\text { National } \\
\text { Assembly }\end{array}$} \\
\hline & 2002 & 2007 & 2002 & 2007 & 2002 & 2007 & 2002 & 2007 & 2002 & 2007 & 2002 & 2007 \\
\hline Very trust & 17.6 & 10.1 & 7.7 & 9.9 & 2.4 & 6.6 & 1.6 & 6.2 & 2.1 & 4.1 & 1.3 & 0.7 \\
\hline Little trust & 59.3 & 48.3 & 47.1 & 52.8 & 33.5 & 45.2 & 28.9 & 45.1 & 21.3 & 34.7 & 9.8 & 12.5 \\
\hline Little distrust & 16.3 & 30.0 & 30.9 & 30.5 & 43.8 & 38.9 & 46.8 & 37.6 & 48.1 & 47.1 & 31.5 & 48.5 \\
\hline Very distrust & 3.4 & 8.9 & 13.0 & 4.6 & 19.6 & 8.6 & 21.1 & 9.5 & 27.8 & 12.9 & 57.0 & 38.7 \\
\hline Non response & 3.3 & 2.7 & 1.3 & 2.3 & 0.7 & 0.8 & 1.7 & 1.6 & 0.7 & 1.3 & 0.4 & 1.7 \\
\hline $\begin{array}{c}\text { Trust/distrust } \\
\text { margin }\end{array}$ & +57.2 & +19.5 & +10.9 & +27.6 & -27.5 & +4.2 & -37.4 & +4.2 & -52.5 & -21.1 & -77.4 & -82.1 \\
\hline
\end{tabular}

Source: Result of National Survey by the Korea Gallup in 2002 and 2007. 
This significant development of civil society was, however, not without problems. Korean civil society has strong faith in democratic principles such as popular voting, political participation, freedom of press, and the rights to criticize the government, but they do not trust political organizations and the government. In addition, they have a relatively low sense of political efficacy. ${ }^{36}$ Citizen's evaluations of democracy after democratization are ambivalent. On the one hand, they want a good quality of democracy, but on the other hand, they do not have faith in public institutions. ${ }^{37}$ As we can see in Table 2, the level of Korean people's trust and faith in public institutions, compared to that of 2002, is steadily rising, but there is still much to be desired. People especially distrust the National Assembly and the presidential office. People's trust in civil organizations was high in 2002, but it dropped significantly in 2007.

The legacy of the authoritarian period, i.e. the structure of conflict between democratic forces and authoritarian forces still overshadows Korean politics and causes fragmentation and mutual distrust between public institutions like the National Assembly, the administration, and civil society. This explains the low level of trust toward decision making and implementation by the National Assembly and by the administration. After democratization, the expansion of the values of post-industrialization improved civil society's political and civic tolerance which is a condition for a genuine democracy, but its trust in political and social institutions is still very low. ${ }^{38}$ This low trust is often expressed in violent protests, and resistance against governmental decision making and implementation of policies. Even after democratization, violent demonstrations, strikes and illegal actions by some civil organizations cause political instability.

\section{Political Crisis and Response of Civil Society: Beyond the Presidential Impeachment in 2004}

A common difficulty that new democracies face in transition and consolidation is clearing out the old legacies of authoritarianism and establishing new democratic laws and orders. In the case of Korea, the process of democratic transition and consolidation was also challenged by various crises of political leadership that had negative impacts on the democratization trend. Political pathology after democratization in Korea can be epitomized as follow: undemocratic party politics plagued by political parties' short-term interests; corruption cases resulting from close and improper connections between politicians and businesses; and political leadership and governance still caught by authoritarian inertia. ${ }^{39}$ Abuses of power, ineptitude and corruption among the political leadership after democratization also invited political crises in the nascent democracy. Particularly, the 2004 presidential impeachment was crucial because the national assembly, for the first time in Korean history, attempted to oust a president elected by the people. However, the political crisis caused by the impeachment attempt was not just a crisis; it was an opportunity for the deepening of Korean democracy. ${ }^{40}$

President Roh Moo-Hyun, who achieved victory in the 16th presidential election held in December 2002, owed his electoral success to the support of the younger generation and the progressives. They were motivated by his reputedly impeccable personal integrity and were mobilized by means of newly developed Internet communication techniques. Many Koreans expressed high hopes that Roh's electoral victory, achieved "without money, organization, and factional ties," would mark the end of bossism politics, namely "three Kims politics" 41 of the previous era. In 2003, however, Korean society was further polarized and fragmented by the confrontation between political groups generally referred to as conservatives and progressives. Korean society was further plagued by social conflicts in the form of frequent labor 
strikes and organized protests. Reports of political corruption and scandals touched the president's trusted confidants and dominated the center stage of politics. ${ }^{42}$

In terms of political leadership, president Roh had neither the power nor the leadership skills that Rhee Seung Man, Park Jung Hee or so called 'three Kims' had nor the leadership of consensus to mediate and coordinate major political interests and blocs. In addition, unlike former leaders, he attempted to get close to ordinary people, but these attempts were interpreted as inexperienced and populist, and as destructive to the basic authority required in a political leader. ${ }^{43}$ Since his inauguration in 2003, President Roh was notable for rhetoric that divided the progressives and the conservatives, and for a series of verbal mistakes. His remarks such as, "I would like to give up presidency. It's too hard." 44 and "I'll ask the people directly if they still support me or not.(after revelations of corruption cases in which his allies were involved)" 45 damaged his authority and status as president. In addition, his rhetoric dividing conservatives and reformists, and the haves and the have-nots invited criticism and complaints from the conservative bloc. Particularly, his statement, "If the illegal fund built in my election camp is more than a tenth of what the Grand National Party (GNP) illegally used, then I'll resign.. ${ }^{, 6}$ extracted a strong response from opposition parties including the GNP. ${ }^{47}$

Table 3. Seat Distribution in the National Assembly in Korea

\begin{tabular}{lcc}
\multicolumn{1}{c}{ Political Parties } & $\begin{array}{c}\text { Result of the 16th General } \\
\text { Election in 2000 }\end{array}$ & As of January 2004 \\
\hline Grand National Party & $133(48.7 \%)$ & $148(54.2 \%)$ \\
New Millennium Democratic Party & $115(42.1 \%)$ & $60(22.0 \%)$ \\
United Liberal Democrats & $17(6.2 \%)$ & $10(3.7 \%)$ \\
Open Uri Party & - & $47(17.2 \%)$ \\
Others & $8(2.9 \%)$ & $8(2.9 \%)$ \\
\hline Total & $273(100.0 \%)$ & $273(100.0 \%)$ \\
\hline
\end{tabular}

Source: Kim, “A Risky Game to Play: The Politics of the Impeachment Game in Korea,” 135.

President Roh left the New Millennium Democratic Party (NMDP) and established a new party called the Open Uri Party (OUP) with his followers, causing political tension. ${ }^{48}$ As we can see in Table 3, the NMDP was a minority in the National Assembly when he became president in 2003. Therefore, president Roh had to get cooperation from the majority opposition GNP for smooth governing. He, however, formed a new, but small OUP and this put him in a more difficult situation for governing. ${ }^{49}$ With Roh's defection and formation of OUP in 2003, NMDP, which had been the ruling party, suddenly became an opposition. Consequently, president Roh made another political enemy and had to deal with two political fronts - GNP and NMDP.

On the surface, the main reason behind Roh's impeachment was his statement supporting his own party for the coming general election in April 2004. The statement was controversial and was ruled inappropriate by the National Election Commission. Opposition parties including the GNP and the NMDP demanded Roh's apology and pledge not to make such statements again, but Roh refused to do so. Furthermore, president Roh said that the Korean people would judge his statement in the coming 17th general election. Roh's refusal and statement further exacerbated an already tense relationship between the president and the opposition. ${ }^{50}$ Following this, the opposition parties led by the NMDP decided to impeach the president, which was passed at the National Assembly, taking advantage of their numerical power in the assembly. ${ }^{51}$ According to the opposition, there were three reasons for the impeachment: 1) violation of the election law through his public support of the OUP; 2) finan-

8 | Journal of Contemporary Eastern Asia, Volume 7, No.2 
cial wrongdoings of Roh's relatives and close supporters; and 3) economic mismanagement resulting in a near crisis situation during the first year of the Roh administration. ${ }^{52}$ Eventually, the case of presidential impeachment was sent to the constitutional court which constitutionally has the power of final judgment. Political turmoil and instability was expected with the judgment by the constitutional court. ${ }^{53}$

Civil society was divided and polarized by pros and cons of the impeachment. ${ }^{54}$ This, however, does not mean that there was serious political chaos in Korea. Some people led by conservative organizations expressed their support for the impeachment. Some others, notably Nosamo (Korean acronym of 'a group of people loving Roh Moo Hyun) staged candle vigils, demanding the retraction of the impeachment. In the midst of pro and con assemblies and gatherings all over the Korea, however, physical clashes or violence were hardly reported and street gatherings and expressions of political views were peaceful. Most people remained calm waiting for the final judgment of the constitutional court and the prime minister, as interim president, managed daily administrative affairs without turbulence.

Table 4. Result of the 17th General Election in 2004

\begin{tabular}{lccccc}
\hline \multirow{2}{*}{ Political Parties } & \multicolumn{2}{c}{ Constituency } & \multicolumn{2}{c}{ Party List } & \multirow{2}{*}{ All Seats } \\
\cline { 2 - 5 } & Seats & $\mathbf{\%}$ & Seats & \% & \\
\hline Open Uri Party & 129 & 53.1 & 23 & 41.1 & $152(50.8)$ \\
Grand National Party & 100 & 41.2 & 21 & 37.5 & $121(40.5)$ \\
Democratic Labor Party & 2 & 0.8 & 8 & 14.3 & $10(3.3)$ \\
New Millennium Democratic Party & 5 & 2.1 & 4 & 7.1 & $9(3.0)$ \\
United Liberal Democrats & 4 & 1.6 & - & - & $4(1.3)$ \\
Others & 3 & 1.2 & - & - & $3(1.0)$ \\
\hline Total & 243 & 100.0 & 56 & 100.0 & $299(100.0)$ \\
\hline
\end{tabular}

Source: National Election Commission. Http://www.nec.go.kr (Search Date: October 30, 2007).

People chose to judge the impeachment in the 17th general election held on 15th April 2004. This election, held before the judgment of the constitutional court, became a de-facto referendum on the presidential impeachment. ${ }^{55}$ Influenced by the impeachment, president Roh's OUP won more than a half of the national assembly seats. For the first time after democratization, a presidential party became the majority in the national assembly. Korean voters, having an unfavorable view of the impeachment, had gone to the polls and had given Roh's OUP a legislative majority. ${ }^{56}$ Regardless of their support for president Roh, people were hurt by the impeachment and the loss of the nation's top leader, the president. After the election, the NMDP became a small party of only nine seats and the GNP had to admit that their decision to impeach the president was wrong.

Eventually, the election result was followed by the Constitutional Court's decision to reinstate the impeached president, Roh Moo-Hyun, ending his two-month incapacitation on 14 May. ${ }^{57}$ President Roh came back to office with his party being the majority in the National Assembly, which gave Roh the power to implement his policies more easily. The political parties that led the impeachment accepted the court's decision and did not pursue any further actions. Therefore, the controversies and turmoil surrounding the impeachment concluded. In this crisis, the Korean political system survived the turmoil and in the end produced a result that was both constitutionally and democratically legitimate. ${ }^{58}$

In sum, if democracy in Korea from 1987 to 2004 was the building of democratic institutions, the restored democratic institutions were fully put into practice over the course of events in the 2004 presidential impeachment. Despite the political crisis stemming from the divisions among the president, ruling party, opposition parties and civil society, the impeachment in 2004 was a good test of the democratic political culture and civic conscious 
after democratization in Korea. The presidential impeachment stemmed from the lack of political leadership demonstrated by the president. The political divisions caused by the presidential impeachment were ruled in the constitutional court. People's views were expressed in the 17th general election. Overall, throughout this process, divisions and tensions were not resolved by physical means causing political insatiability, but were dealt with institutionally. Civil society responded to the presidential impeachment waiting for the review of constitutional court. This experience demonstrated the consolidation of democracy in Korea and is evidence of a mature political culture.

\section{Conclusion: For More Consolidation of Democracy}

The political crisis prompted by the presidential impeachment was a joint product of a lack of leadership and of clashing interests among major political forces in Korea. At the early stage of his presidency, Roh failed to be a leader of mediation, coordination and consultation. Through abrasive and harsh remarks and statements, Roh displayed 'politics of clash' or 'politics of brinkmanship,' and invited impeachment by the strong oppositions. ${ }^{59}$ Nevertheless, Korean civil society, rather than creating social turmoil fermented by political divisions and interests, chose political stability through democratic procedures and rules, the election, not a protest on the street, displaying mature political culture and civic consciousness.

At the time of this study, Korean politics is still clearing up the debris of the 2004 presidential impeachment. Therefore the political leadership and civil society are required to make continuous efforts to consolidate democracy. After the 2004 general election and constitutional court judgment, the reform policies of Roh's administration did not make any visible impact, and the clashes between progressives and conservatives which are a legacy of authoritarian politics, continue. ${ }^{60}$ At the level of political leadership, the president's disregard for the opposition and his verbal errors continue and make political clashes. At the level of civil society, civil organizations still are not completely free from problems such as illegal strikes of labor unions and physical clashes between protesters and police at political rallies.

Consolidating a new democracy after democratization is not easy. It is not simply about repairing institutions such as the constitution, electoral laws and political party laws. It is not simply about guaranteeing civil rights, freedom of political participation and fair elections. Democratic consolidation not only requires institutional and procedural democracy, but it also calls for democratic leadership, and democratic attitude and orientation of the civil society. Challenges, not confirming existing laws and regulations, to political leadership and following political crises cause political instability. It is the result of failure to reach an agreement on the rules of political game between political leadership and civil society, and to setup democratic political model. Carving democratic law and order into a political system, and clearing up the old legacies of authoritarian politics is not simply the task of political leaders. The civil society should share the burden.

Authoritarian legacy and old political customs related to authoritarianism are not just the symptoms of the political leadership of new democracy, but are embedded in the society. The way to overcome the challenges to political leadership and political crises in the democratic transition and consolidation in a post-democratization period is to build a new democratic political model, appropriate for the new democratic law and order. In other words, political leaders and civil society have to accept democratic law and order that were established in the transition period as the only and sole 'rule of game' in politics and have to internalize the democratic political procedure and culture in them, on top of institutional and procedural democracy. 


\section{References}

\section{Korean References}

Auh, Soo Young. 2004. "Gachibyeonhwa-wa Minjuju-ui Gonggohwa (Value Changes and Consolidation of Democracy in Korea)." Hankookjeongchihakhoibo (Korean Political Science Review), Vol. 38, No. 1, pp. 193-214.

Bae, Han-Dong. 2004. "Hankook minjuju-ui gonggohwa kwajeong-ui simindanche-ui yeokhal (The Role of NGOs in Consolidating Democracy in Korea)." Daihanjeongchihakhoibo (Daihan Political Science Review), Vol. 12, No. 1, pp. 393-417.

Cho, Sungdai. 2004. "Jeongchi event, Jeongdangjijido, grigo 17dai chongsun (Political Events, Party Support, and the 17th General Election in Korea)." 21 segi jeongchihakhoibo (21st Century Political Science Review), Vol. 14, No. 3, pp. 63-82.

Choi, Han Soo. 2006. "Roh Moo-Hyon daitongryeong tanhaek-ei kwanhan sogo (A Study of Presidential Impeachment: The Case of President Roh Moo-Hyun's Impeachment in Korea).” Daihanjeongchihakhoibo (Daihan Political Science Review), Vol. 13, No. 3, pp. 97-119.

Chosun Ilbo (Chosun Daily), March 12, 2004.

Hahm, Seong deuk. 2002. "Hankook Daitongryeong-ui saeroun yeokhalkwa leadership (New Roles and Leadership of the President in Korea)." Haengjeongronchong (Public Administration Review), Vol. 40, No. 3, pp. 97-121.

Jeong, Yunjae. 2003. Jeongchi-leadershipkwa hankookminjuju-ui (Political Leadership and Korean Democracy). Seoul: Nanam.

Joong-ang Ilbo (Joong-ang Daily), May 21, 2003; October 10, 2003; December 14, 2003; March 11, 2004.

Kim, Ho Jin. 2006. Daitongryeongkwa leadership (President and Leadership). Seoul: Cheongrim Chulpan.

Kim, Hyeok Rae. 1999. "Hankook Bujeongbupae-ui Yoohyeongkwa siltae (The Patterns and Realities of Corruption in Korea)." Chung-in Moon and Jong Ryn Mo, eds., Hankook-ui bujeongbupae (Corruption in Korea). Seoul: Oreum, pp. 15-34.

Kim, Yung-Myung. 2005. "Hankookminjuju-ui-ui seongkyeok-kwa kwaje (The Characteristics and the Problems of Korean Democracy)." Bikyominjuju-ui yeongu (Comparative Democracy Studies), Vol. 1, No. 2, pp. 63-97.

Lee, Dong-Yoon. 2007. "Kookhoi-ui Ibpeobkwajeongkwa simindanche-ui yeokhal (Legislative Process and the Role of Civil Groups)." Hankookjeoungdanghakhoibo (Korean Party Studies Review), Vol. 6, No. 1, pp. 165-92.

Lim, Sung ho. 2007. "Hankook minjuhwa-wa kookga-siminsahoi yibunbeob-ui hankye (Korean Democratization and the Limitation of State-Civil Society Dichotomy." Paper presented on Special Conference on Twenty Years of Korean Democratization: Democracy and Leadership, held by the Korean Political Science Association (June 1), pp. 110-35.

Lim, Hyeok Baek. 1990. "Hankookeseo-ui minjuhwakwajeong bunseok: Jeonryakjeok suntaek-ironeul jungsimoero (Analysis of Democratization Process: Strategic Choice Theory)." Hankookjeongchihakhoibo (Korean Political Science Review), Vol. 24, No. 1, pp. 51-77.

National Election Commission. Http://www.nec.go.kr (Search Date: October 30, 2007).

Park, Myung-Lim. 2004. "Tanhaeksatae-wa hankook minjuju-ui: uimi-wa phajang (Impeachment and Democracy in Korea: Imprecations and wavelength)." Dangdai-bipyung (Current Critics), Vol. 26, pp. 27-41. 
2005. "Heonbeob, heonbeobjueui, grigo hankook minjuju-eui (Constitution, Constitutionalism, and Democracy in South Korea)." Hankookjeongchihakhoibo (Korean Political Science Review), Vol. 39, No. 1, pp. 253-76.

\section{English References}

Armony, Ariel C. and Hector E. Schamis. 2005. "Babel in Democratization Studies." Journal of Democracy, Vol. 16, No. 4, pp. 113-128.

Baker, Bruce. 2001. "Quality Assessment of Democracy in the Third World." Jeff Haynes, ed. Democracy and Political Change in the 'Third World.' London and New York: Routledge, pp. 21-34.

Blais, André and Stéphane Dion. 1990. "Electoral Systems and the Consolidation of New Democracies." Diane Ethier, ed. Democratic Transition and Consolidation in Southern Europe, Latin America and Southeast Asia. London: Macmillan Press, pp. 250-68.

Carothers, T. 2002. "The End of the Transition Paradigm." Journal of Democracy, Vol. 13, No. 1, pp. 5-21.

Dahl, Robert A. 1971. Polyarchy: Participation and Opposition. New Heaven: Yale University Press.

Diamond, Larry. 1996. "Is the Third Wave Over?" Journal of Democracy, Vol. 7, No. 3, pp. 20-37.

Diamond, Larry. 1997. "Introduction: In Search of Consolidation." Larry Diamond, Marc F. Plattner, Yun-han Chu, and Hung-mao Tien, eds. Consolidating the Third Wave Democracies. Baltimore and London: The Johns Hopkins University Press, pp. xiii-xlvii.

1999. Developing Democracy toward Consolidation. Baltimore and London: The Johns Hopkins University Press.

Engberg, Jan and Svante Ersson. 2001. "Illiberal Democracy in the 'Third World': An Empirical Enquiry." Jeff Haynes, ed. Democracy and Political Change in the 'Third World. 'London and New York: Routledge, pp. 35-54.

Ethier, Diane. 1990. "Processes of Transition and Democratic Consolidation: Theoretical Indicators." Diane Ethier, ed. Democratic Transition and Consolidation in Southern Europe, Latin America and Southeast Asia. London: Macmillan Press, pp. 3-20.

Freedom House. Http://www.freedomhouse.org (Search Date: April 6, 2007).

Fukuyama, Francis, Björn Dressel, and Boo-Seung Chang. 2005. "Facing the Perils of Presidentialism?" Journal of Democracy, Vol. 16, No. 2 (April), pp. 102-116.

Hahm, Chaihark and Sung Ho Kim. 2005. "Constitutionalism on Trial in South Korea." Journal of Democracy, Vol. 16, No. 2 (April), pp. 28-42.

Haynes, Jeff. 2001. "Introduction: The 'Third World' and the Third Wave of Democracy." Jeff Haynes, ed. Democracy and Political Change in the 'Third World.' London and New York: Routledge, pp. 1-20.

Huntington, Samuel P. 1991. The Third Wave: Democratization in the Late Twentieth Century. Norman, O.K.: University of Oklahoma Press. 13.

1996. "Democracy for the Long Haul." Journal of Democracy, Vol. 7, No. 2, pp. 3-

Kihl, Young Whan. 2005. Transforming Korean Politics: Democracy, Reform, and Culture. Armork, N.Y. and London, U.K.: M.E. Sharpe (East Gate Book).

Kim, Hee Min. 2006. "A Risky Game to Play: The Politics of the Impeachment Game in Korea." Dongseo-Yeonku (Journal of East and West Studies), Vol. 18, No. 1, pp. 127-149. 
Kim, Uichol. 2002. "Democracy, Leadership and Political Culture in Korea: With Specific Focus on Political Efficacy and Trust." Korean Journal of Psychological and Social Issues, Vol. 8, No. 2, pp. 137-170.

Korten, David C. 1972. “Task: Situational Determinants of Leadership Structure." Glenn D. Paige, ed. Political Leadership: Readings for an Emerging Field. New York: The Free Press, pp. 146-164.

Lee, Hong Yung. 2004. "South Korea in 2003: A Question of Leadership?" Asian Survey, Vol. 44, No. 1 (January/February), pp. 130-138.

Lie, John and Myoungkyu Park. 2006. "South Korea in 2005: Economic Dynamism, Generational Conflicts, and Social Transformations." Asian Survey, Vol. 46, No. 1 (January/February), pp. 56-62.

Linz, Juan J. and Alfred Stepan. 1996. "Toward Consolidated Democracy." Journal of Democracy, Vol. 7, No. 2, pp. 14-33.

Macedo, Stephen. 2000. "Transitions to What? The Social Foundations of the Democratic Citizenship." James F. Hollifield and Calvin Jillson, eds. Pathways to Democracy: The Political Economy of Democratic Transitions. New York and London: Routledge, pp. 53-70.

Park, Byeong-Seog. 1995. "Political Corruption in South Korea: Concentrating on the Dynamics of Party Politics." Asian Perspective, Vol. 19, No. 1 (Spring-Summer), pp. 163193.

Park, Jong-Min and Doh Chull Shin. 2006. "Do Asian Values Deter Popular Support for Democracy in South Korea?" Asian Survey, Vol. 46, No. 3 (May/June), pp. 341-361.

Pye, Lucian W. 2000. "Democracy and Its Enemies.” James F. Hollifield and Calvin Jillson, eds. Pathways to Democracy: The Political Economy of Democratic Transitions. New York and London: Routledge, pp. 21-36.

Schedler, Andreas. 1998. "What is Democratic Consolidation?" Journal of Democracy, Vol. 9, No. 2, pp. 91-107.

Schmitter, Philippe C. and Terry Lynn Karl. 1993. "What Democracy Is ... and Is Not." Larry Diamond and Marc F. Plattner, eds. The Global Resurgence of Democracy. Baltimore and London: The Johns Hopkins University Press, pp. 39-52.

Sørensen, Georg. 1993. Democracy and Democratization: Processes and Prospects in a Changing World. Boulder and Oxford: Westview Press.

Steinberg, David I. and Myung Shin. 2006. "Tensions in South Korean Political Parties in Transition: From Entourage to Ideology?" Asian Survey, Vol. 46, No. 4 (July/August), pp. 517-537.

Zakaria, Fareed. 1997. "The Rise of Illiberal Democracy.” Foreign Affairs, Vol. 76, No. 6, pp. 22-43.

2003. The Future of Freedom: Illiberal Democracy at Home and Abroad. New York:

W. W. Norton \& Co.

\section{Notes}

${ }^{1}$ Samuel P. Huntington, The Third Wave: Democratization in the Late Twentieth Century (Norman, O.K.: University of Oklahoma Press, 1991).

${ }^{2}$ Phillipe C. Schmitter and Terry Lynn Karl, "What Democracy Is ... and Is Not," in The Global Resurgence of Democracy, eds. Larry Diamond and Marc F. Plattner (Baltimore and London: The Johns Hopkins University Press, 1993), 40.

${ }^{3}$ Robert A. Dahl, Polyarchy: Participation and Opposition (New Heaven: Yale University Press, 1971), 3-7.

${ }^{4}$ Andreas Schedler, "What is Democratic Consolidation?” Journal of Democracy 9 (2) (1998): 91. 
${ }^{5}$ Larry Diamond, "Is the Third Wave Over?" Journal of Democracy 7 (3) (1996): 21; Bruce Baker, "Quality Assessment of Democracy in the Third World," in Democracy and Political Change in the 'Third World', ed. Jeff Haynes (London and New York: Routledge, 2001), 21-34.

${ }^{6}$ Georg Sørensen, Democracy and Democratization: Processes and Prospects in a Changing World (Boulder and Oxford: Westview Press, 1993), 40.

${ }^{7}$ Jeff Haynes, "Introduction: The 'Third World' and the Third Wave of Democracy," in Democracy and Political Change in the 'Third World', ed. Haynes, 7.

${ }^{8}$ Andreas, "What is Democratic Consolidation?" 97-98.

${ }^{9}$ André Blais and Stéphane Dion, "Electoral Systems and the Consolidation of New Democracies," in Democratic Transition and Consolidation in Southern Europe, Latin America and Southeast Asia, ed. Diane Ethier (London: Macmillan Press, 1990), 251.

${ }^{10}$ Juan J. Linz and Alfred Stepan, "Toward Consolidated Democracy," Journal of Democracy 7 (2) (1996): 1433.

${ }^{11}$ Larry Diamond, Developing Democracy toward Consolidation (Baltimore and London: The Johns Hopkins University Press, 1999), 34-49.

${ }^{12}$ Ariel C. Armony and Hector E. Schamis, "Babel in Democratization Studies," Journal of Democracy 16 (4) (2005): 113-114.

${ }^{13}$ Fareed Zakaria, The Future of Freedom: Illiberal Democracy at Home and Abroad (New York: W. W. Norton \& Co, 2003).

${ }^{14}$ Jan Engberg and Svante Ersson, "Illiberal Democracy in the 'Third World': An Empirical Enquiry," in Democracy and Political Change in the 'Third World', ed. Haynes, 40.

${ }^{15}$ Fareed Zakaria, “The Rise of Illiberal Democracy," Foreign Affairs 76 (6) (1997): 24; T. Carothers, "The End of the Transition Paradigm," Journal of Democracy 13 (1) (2002): 5-21.

${ }^{16}$ Samuel Huntington, "Democracy for the Long Haul," Journal of Democracy 7 (2) (1996): 6.

${ }^{17}$ Lucian W. Pye, "Democracy and Its Enemies," in Pathways to Democracy: The Political Economy of Democratic Transitions, eds. James F. Hollifield and Calvin Jillson (New York and London: Routledge, 2000), 29.

${ }^{18}$ Larry Diamond, "Is the Third Wave Over?" 33; Stephen Macedo, "Transitions to What? The Social Foundations of the Democratic Citizenship," in Pathways to Democracy: The Political Economy of Democratic Transitions, eds. Hollifield and Jillson, 53.

${ }^{19}$ David C. Korten, “Task: Situational Determinants of Leadership Structure," in Political Leadership: Readings for an Emerging Field, ed. Glenn D. Paige (New York: The Free Press, 1972), 151-152.

${ }^{20}$ Larry Diamond, "Introduction: In Search of Consolidation," in Consolidating the Third Wave Democracies, eds. Larry Diamond, Marc F. Plattner, Yun-han Chu, and Hung-mao Tien (Baltimore and London: The Johns Hopkins University Press, 1997), xxxi.

${ }^{21}$ Diane Ethier, "Processes of Transition and Democratic Consolidation: Theoretical Indicators," in Democratic Transition and Consolidation in Southern Europe, Latin America and Southeast Asia, ed. Diane Ethier, 17.

${ }^{22}$ Diamond, "Introduction: In Search of Consolidation," xvii.

${ }^{23}$ Linz, and Stepan, "Toward Consolidated Democracy," 18.

${ }^{24}$ Lim Hyeok Baek, "Hankookeseo-ui minjuhwakwajeong bunseok: Jeonryakjeok suntaek-ironeul jungsimoero (Analysis of Democratization Process: Strategic Choice Theory)," Hankookjeongchihakhoibo (Korean Political Science Review) 24 (1) (1990).

${ }^{25}$ Kihl Young Whan, Transforming Korean Politics: Democracy, Reform, and Culture (Armork, N.Y. and London, U.K.: M.E. Sharpe and East Gate Book, 2005), 21.

${ }^{26}$ It is common to refer to 'Polity IV' index to evaluate a country's democracy. However, the index only covers till 2004 and does not reflect recent developments until 2006.

${ }^{27}$ Hahm Seong deuk, "Hankook Daitongryeong-ui saeroun yeokhalkwa leadership (New Roles and Leadership of the President in Korea)," Haengjeongronchong (Public Administration Review) 40 (3) (2002): 99.

${ }^{28}$ Park Jong-Min and Doh Chull Shin, "Do Asian Values Deter Popular Support for Democracy in South Korea?" Asian Survey 46 (3) (2006): 361.

${ }^{29}$ Kim Ho Jin $(2006,442)$ has an interesting evaluation of three former presidents from the perspective of political leadership. Roh Tae Woo, who announced 6.29 statement in 1987 was very indecisive political leader who did not do what he had to do. Kim Young Sam, who attempted to correct what was done wrong in the past, has dreamed of a successful first civilian rule, but has failed to run the country as he dreamed of. Kim Dae Jung, who overcame the economic crisis, made significant progress in the North-South relationship but was not so successful in managing the country.

${ }^{30}$ Park Myung-Lim, "Tanhaeksatae-wa hankook minjuju-ui: uimi-wa phajang (Impeachment and Democracy in Korea: Imprecations and wavelength)," Dangdai-bipyung (Current Critics) 26 (2004): 36.

${ }^{31}$ Jeong Yunjae, Jeongchi-leadershipkwa hankookminjuju-ui (Political Leadership and Korean Democracy) (Seoul: Nanam, 2003), 476. 
${ }^{32}$ Growing corruption of politicians and public officials in Korea is partly due to distorted party politics, heightened competition in election after democratization, and the increased cost of politics following because of more competitive election. Park Byeong-Seog, "Political Corruption in South Korea: Concentrating on the Dynamics of Party Politics," Asian Perspective 19 (1) (1995): 165-172.

${ }^{33}$ Kim Hyeok Rae, "Hankook Bujeongbupae-ui Yoohyeongkwa siltae (The Patterns and Realities of Corruption in Korea)," in Hankook-ui bujeongbupae (Corruption in Korea), eds. Chung-in Moon and Jong Ryn Mo (Seoul: Oreum, 1999), 15-16.

${ }^{34}$ KICAC was first setup in 2001 under President's direct supervision by the Anti-Corruption Act of Korea, but later in 2005, became an independent institution.

${ }^{35}$ Bae Han-Dong, "Hankook minjuju-ui gonggohwa kwajeong-ui simindanche-ui yeokhal (The Role of NGOs in Consolidating Democracy in Korea)," Daihanjeongchihakhoibo (Daihan Political Science Review) 12 (1) (2004): 411; Lee Dong-Yoon, "Kookhoi-ui Ibpeobkwajeongkwa simindanche-ui yeokhal (Legislative Process and the Role of Civil Groups)," Hankookjeoungdanghakhoibo (Korean Party Studies Review) 6 (1) (2007): 174175.

${ }^{36}$ Kim Uichol, "Democracy, Leadership and Political Culture in Korea: With Specific Focus on Political Efficacy and Trust," Korean Journal of Psychological and Social Issues 8 (2) (2002): 137-170.

${ }^{37}$ According to a Korea Gallup poll done from 16 April to 4 May 2007 with 1,014 samples, Korean's evaluation of Korean democracy scored 6.2 in 1 to 10 scale. To another question - does democracy fit into Korea?- 24.4\% of respondent answered in negative way (below 4 points), $42.3 \%$ answered in neutral way (5 to 6 points), and $31.2 \%$ answered 'fits well' (7 to 10 points). In average, people gave 5.6 points to democracy in Korea. Lim Sung Ho, "Hankook minjuhwa-wa kookga-siminsahoi yibunbeob-ui hankye (Korean Democratization and the Limitation of State-Civil Society Dichotomy," Paper presented on Special Conference on Twenty Years of Korean Democratization: Democracy and Leadership, held by the Korean Political Science Association (June 1, 2007), 117.

${ }^{38}$ Auh Soo Young, "Gachibyeonhwa-wa Minjuju-ui Gonggohwa (Value Changes and Consolidation of Democracy in Korea)," Hankookjeongchihakhoibo (Korean Political Science Review) 38 (1) (2004): 202-208.

${ }^{39}$ Bae, "Hankook minjuju-ui gonggohwa kwajeong-ui simindanche-ui yeokhal (The Role of NGOs in Consolidating Democracy in Korea)," 415.

${ }^{40}$ Park, "Tanhaeksatae-wa hankook minjuju-ui: uimi-wa phajang (Impeachment and Democracy in Korea: Imprecations and wavelength), 29; Hahm Chaihark and Sung Ho Kim, "Constitutionalism on Trial in South Korea," Journal of Democracy 16 (2) (2005): 28-42.

${ }^{41}$ One of the cardinal elements of Korean politics after democratization is that political parties have been their regional strongholds. After democratization, the era of the "three Kims" (Kim Dae Jung, Kim Young Sam, and Kim Jong Pil) brought intense political partisanship based on their respective provinces of origin, Cholla, Kyongsang, and Chungchong. David I. Steinberg and Myung Shin, "Tensions in South Korean Political Parties in Transition: From Entourage to Ideology?" Asian Survey 46 (4) (2006): 527.

${ }^{42}$ Lee Hong Yung, "South Korea in 2003: A Question of Leadership?” Asian Survey 44 (1) (2004): 130-131.

${ }^{43}$ Kim Yung-Myung, "Hankookminjuju-ui-ui seongkyeok-kwa kwaje (The Characteristics and the Problems of Korean Democracy)," Bikyominjuju-ui yeongu (Comparative Democracy Studies) 1 (2) (2005): 65.

${ }^{44}$ Joong-ang Ilbo (Joong-ang Daily), May 21, 2003.

45 Joong-ang Ilbo (Joong-ang Daily), October 10, 2003.

46 Joong-ang Ilbo (Joong-ang Daily), December 14, 2003.

${ }^{47}$ On December 14, president Roh declared that if the illegal funds collected by his camp amounted to one-tenth of what the GNP illegally accumulated, he would step down from the presidency and retire from politics. One day after this statement, Lee Hoi Chang, the GNP's defeated presidential candidate, publicly said he would take all responsibility, both legal and moral, for illegal fundraising by the GNP, and would be ready to fully cooperate with the prosecutor's office and to take any punishment including jail term, while asking for leniency for his subordinates under investigation. Among other things, this move was viewed as subtle pressure on president Roh to accept all responsibility for the illegal fundraising by his campaign camp.

${ }^{48}$ It is common for political parties in Korea are established in preparation for presidential elections and general elections, and disassembled after elections. Korean political parties are formed as grudging and precarious expedients by individuals who would rather reach power by themselves. Party purpose is not rule, it is access to rule. Political party in Korea is a volatile phenomenon, more dependent on its leader than on any ideology or formal organizational structure. In other words, the leader is the party. Steinberg and Shin, "Tensions in South Korean Political Parties in Transition," 518.

${ }^{49}$ Kim, Hee Min, "A Risky Game to Play: The Politics of the Impeachment Game in Korea," Dongseo-Yeonku (Journal of East and West Studies) 18 (1) (2006): 134.

${ }^{50}$ Choi Han Soo, "Roh Moo-Hyon daitongryeong tanhaek-ei kwanhan sogo (A Study of Presidential Impeach- 
ment: The Case of President Roh Moo-Hyun's Impeachment in Korea,." Daihanjeongchihakhoibo (Daihan Political Science Review) 13 (3) (2006): 110.

${ }^{51}$ On 12 March 2004, while ruling party assemblymen were occupying the speaker's seat to sabotage the impeachment motion, 195 assemblymen took part in the voting. The impeachment was passed with 193 consents (129 from Grand National Party, 53 from Democratic Party, 8 from United Liberal Democrats, 5 independent assemblymen) and two against. Presidential impeachment requires at least 181 consents which is two-third of total 271 assemblymen. Chosun Ilbo (Chosun Daily), March 12, 2004.

${ }^{52}$ Kim, "A Risky Game to Play: The Politics of the Impeachment Game in Korea," 136.

${ }^{53}$ Presidential impeachment by National Assembly, according to clause 65 of Constitution, has to be proposed by a simple majority of assembly and can be passed with $2 / 3$ consent. The passed impeachment motion is submitted to constitutional court. The court has to convene plenipotentiary meeting of justices within 180 days. If six out of nine justices consent, then the impeachment becomes effective and the president is dismissed.

${ }^{54}$ According to an opinion survey, more than $60 \%$ of people were of opinion that the president had to apologize to the opposition parties, but the same $60 \%$ of people said the presidential impeachment was wrong. Joong-Ang Ilbo (Joong-Ang Daily), March 11, 2004.

${ }^{55}$ Park Myung-Lim, "Heonbeob, heonbeobjueui, grigo hankook minjuju-eui (Constitution, Constitutionalism, and Democracy in South Korea)," Hankookjeongchihakhoibo (Korean Political Science Review) 39 (1) (2005): 256; Cho Sungdai, "Jeongchi event, Jeongdangijiido, grigo 17dai chongsun (Political Events, Party Support, and the 17th General Election in Korea)," 21 segi jeongchihakhoibo (21st Century Political Science Review) 14 (3) (2004): 64.

${ }^{56}$ Francis Fukuyama, Björn Dressel, and Boo-Seung Chang, "Facing the Perils of Presidentialism?” Journal of Democracy 16 (2) (2005): 109.

${ }^{57}$ Korean Constitutional Court is composed of nine justices with six year term. According to the check and balance principle, president appoints three, national assembly select three and the chief justice of Supreme Court designate another three.

${ }^{58}$ Fukuyama, Dressel, and Chang, "Facing the Perils of Presidentialism?" 109.

${ }^{59}$ Choi, "Roh Moo-Hyon daitongryeong tanhaek-ei kwanhan sogo (A Study of Presidential Impeachment: The Case of President Roh Moo-Hyun's Impeachment in Korea)," 117-118.

${ }^{60}$ John Lie and Myoungkyu Park, "South Korea in 2005: Economic Dynamism, Generational Conflicts, and Social Transformations," Asian Survey 46 (1) (2007): 58-62. 